\title{
Control of Gene Expression
}

\author{
N. Maclean Department of Biology, University of Southampton, England \\ May/June 1976, xii + 348 pp., $£ 7.80 / \$ 19.25 \quad 0.12 .464950 .5$
}

This book sets out to review the important experimental systems in current use in the general area of the control of gene expression. It will be invaluable to all those researching into cell differentiation and gene expression in biochemical, medical, physiological and genetic laboratories, and to undergraduates reading biochemistry, cell biology and genetics.

\section{Contents}

The control of gene expression and its levels of action. Gene expression in prokaryotes. Experimental systems of differential gene function in eukaryotes - systems involving one type of protein. Experimental systems of differential gene function in eukaryotes systems of limited complexity. Experimental systems of differential gene function in eukaryotes - systems not well understood in molecular terms. RNA involvement in gene expression. General concepts of gene regulation. Author index. Subject index.

\section{The Genetics and Biology of Drosophila}

\section{Volumes 1a, 1b, 1c}

edited by M. Ashburner Department of Genetics, University of Cambridge, England and E. Novitski Department of Biology, University of Oregon, Eugene, Oregon, USA

\section{Volume 1 a}

April/May 1976, xx+530 pp., £16.80/\$41.75 0.12 .064901 .2

\section{Volume 1 b}

July/August 1976, xx+504 pp., f16.80/\$42.50 0.12 .064902 .0

\section{Volume 1 c}

August/September 1976, xx+510 pp., £16.80/\$42.50 0.12 .064903 .9

Studies with Drosophila, in particular with Drosophila melanogaster, have contributed more to our understanding of heredity than'studies with anyjother eukaryotes. Surprisingly, this is the first attempt since 1925 to publish a comprehensive account of the biology and genetics of Drosophila. It aims to collate the dauntingly large literature on the subject and to make more accessible the private language of the Drosophilist. In this way the work will be of value both to established research workers and to biologists in general. This remarkable and ambitious work has been divided into three series of volumes. Volumes $1 \mathrm{a}, 1 \mathrm{~b}$ and $1 \mathrm{c}$ deal with the formal genetics of Drosophila, Volume 2 deals with its biology and development and Volume 3 with its evolution and ecology.

\section{Academic Press}

\section{London New York San Francisco}

A Subsidiary of Harcourt Brace Jovanovich, Publishers

24-28 Oval Road, London NW1, England

111 Fifth Avenue, New York, NY 10003, USA

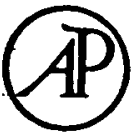

Australian office: PO Box 300, North Ryde, NSW 2113, Australia 


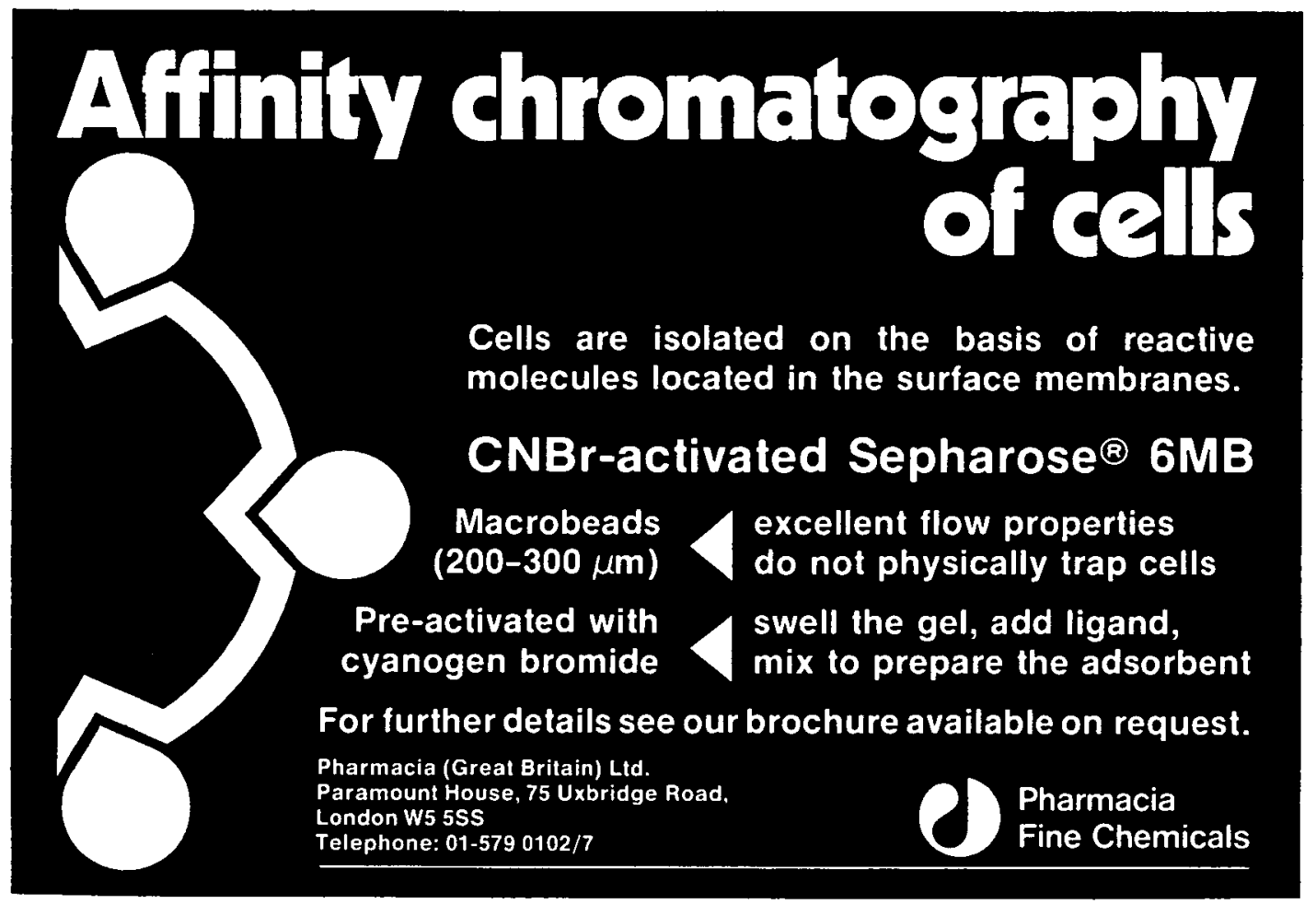

\section{ANNOTATED BIBLIOGRAPHIES}

These are duplicates of bibliographies prepared on request at the Commonwealth Bureau of Animal Breeding and Genetics, The King's Buildings, West Mains Road, Edinburgh, EH9 3JX, Scotland. In addition to the full title reference, the abstract published in Animal Breeding Abstracts is reproduced. Supplementary bibliographies (marked A and B) are prepared from time to time to bring some of the earlier ones up to date. The bibliographies can be obtained on application to the Director. The prices quoted include postage by ordinary mail, and the remittance should be sent with the order unless you want it posted by air mail. If the material is to be sent by air mail, do not send money with your request, you will receive an invoice which includes air mail postage. Some of the most recent bibliographies are listed below, but a full list is obtainable from the Bureau.

Number

286

287

288

289

290

291

292

293

294

295

\section{Subject}

Blackhead Persian Sheep

The estimation of egg production: partseason records and their use in selection

Oestrus diagnosis, factors affecting it and its relationship to conception in cattle, sheep and pigs

The effect of parity on birth weight and growth of cattle

Frozen semen in the pig

Goat production in the tropics

Milk recording methods (revised and updated: replaces 138 and 138 A)

Economic aspects of animal breeding

Birth weight and early body weight in sheep: entire males $v$. females

Conception rate in relation to:

(1) age of fresh semen, and

(2) time of insemination
Period
covered

1951-73

1952-74

1951-75

Number of references

35

54

120

1951-74

38

1958-74

1968-75

1951-74

49

1957-75

1962-75

1952-75

125
$£ 2.70$

£1.20

$£ 1.20$

£1.65

£1.95

Price

$£ 1.35$

£1.65

£1.95

$£ 1.95$

£2.70 


\section{GENETICAL

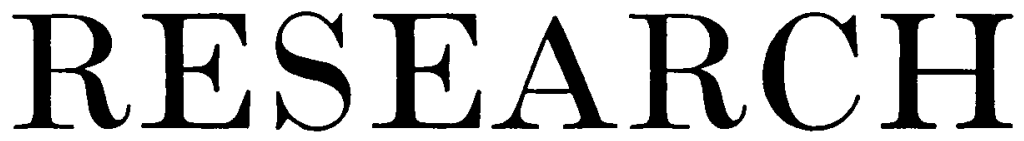

EDITORIAL BOARD

CHARLOTTE AUERBACH W. HAYES

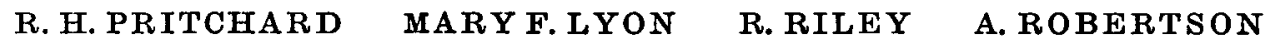

EXECOTIVE EDITOR

E. C. R. REEVE

ASSISTANT EXEOUTIVE EDITOR

N. S. WILLETTS

Volume 27. 1976

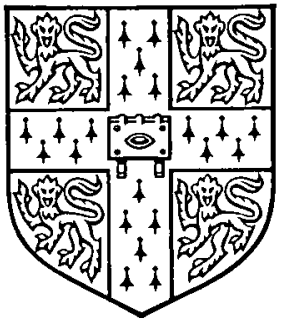

CAMBRIDGE

AT THE UNIVERSITY PRESS

1976 


\section{P UBLISHED B Y}

THE SYNDICS OF THE CAMBRIDGE UNIVERSITY PRESS

Bentley House, 200 Euston Road, London NW1 2DB American Branch: 32 East 57th Street, Now York, N.Y. 10022

(C) Cambridge University Press, 1975 


\section{CONTENTS}

No. 1 (February 1976)

Obituary: C. H. Waddington

page 1

WaLlaCe, MargareT E. Mapping an invisible lethal in the mouse

Claxton, J. H. and Kongsuwan, Kritaya. Non-autonomy in achaete mosaics of Drosophila

Mafizul Islam, A. B. M., HILL, W. G. and Land, R. B. Ovulation rate of lines of mice selected for testis weight

Avise, JoHN C. Genetics of plate morphology in an unusual population of threespine sticklebacks (Gasterosteus aculeatus)

Galizzi, A., Siccardi, A. G., Mazza, G., Canosi, U. and Polsinelit, M. A recombination test to classify mutants of Bacillis subtilis of identical phenotype

Bond, D. J. and MacDonald, M. D. The genetic control of protoperithecial production in Sordaria brevicollis

Chapman, Vtctor, Miller, T. E. and Riley, Ralph. Equivalence of the A genome of bread wheat and that of Triticum urartu

Kadfman, M. H. The incidence of chromosomally unbalanced gametes in $\mathbf{T}(14 ; 15) 6$ Ca heterozygote mice

Haigh, John and Smith, John MaYnaRD. The hitch-hiking effect - a reply

Short Paphr

Evans, I. H. and Wrrkie, D. Mitochondrial factors in the utilization of sugars in Saccharomyces cerevisiae

No. 2 (April 1976)

EDITORIAL NOTE

Chang, Sheng-Yung and Kung, Ching. Selection and analysis of a mutant Paramedium tetraurelia lacking behavioural response to tetraethylammonium

Ruiz, Francoise, Adoutte, Andre, Rossingnol, Michìle and Beisson, JANINE. Genetic analysis of morphogenetic processes in Paramecium. I. A mutation affecting trichocyst formation and nuclear division

Berger, James D. Gene expression and phenotypic change in Paramecium tetraurelia exconjugants

Hrwatashi, KoICHI and Myohara, KoJi. A modifier gene involved in the expression of the dominant mating type allele in Paramecium caudatum 
Na, Stephen F. Extra cytoproct mutant in Paramecium tetraurelia: a genetical study

DiLts, JUdith A. Covalently closed, circular DNA in kappa endosymbionts of Paramecium

AUfDerheide, Kard. Synchrony of division in mass cultures of Paramecium tetraurelia by a selective density-labelling technique

Korzomi, Sadaaki and Kobayashi, Sumiko. A study on the mate-killer toxin by microinjection in Paramecium

JONES, WARREN R. Oral morphogenesis during asexual reproduction in Paramecium tetraurelia

Sundararaman, V. and Hanson, EarL D. Longitudinal microtubules and their functions during asexual reproduction in Paramecium tetraurelia

GrImes, GARY W. Laser microbeam induction of incomplete doublets of Oxytricha fallax

Prenr, JoHn R., JR. Quantitative predictions of random segregation models of the ciliate macronucleus

Nybera, Dennis. Are macronuclear subunits in Paramecium functionally diploid?

Brrky, C. William, JR and Skavaril, Russelt V. Maintenance of genetic homogeneity in systems with multiple genomes

Mryake, Akio and Bleyman, Lea K. Gamones and mating types in the genus Blepharisma and their possible taxonomic application

Pelvat, B. and DE Halcer, G. Macronuclear DNA in Stentor coeruleus: a first approach to its characterization

BUTZEL, H. M. and MAYER, L. Effects of actinomycin D and puromycin upon excystment of Didinium nastutum

NANNEY, D. L. Calcium chloride effects on nuclear development in Tetrahymena

Colgrn-Bukovsan, Laura AnN. The genetics of mating type in the suctorian Tokophyra lemnarum

Chelala, Cesar A. and Margolin, Paul. Evidence that HT mutant strains of bacteriophage P22 retain an altered form of substrate specificity in the formation of transducing particles in Salmonella typhimurium

Drcamelit, Ralph Francis and Balbinder, Elias. The association of tryptophan synthetase subunits from Escherichia coli and Salmonella typhimurium in homologous and heterologous combinations

Ronen, Ammram and Levine, Mrron. Lysogenization by phage P22 carrying amber mutations in genes 12 and 18 
Pasternak, J. and Barrell, R. Quantitation of nuclear DNA in Ascaris lumbricoides: DNA constancy and chromatin diminution

A selected list of the published writings of Tracy M. Sonneborn

No. 3. (June 1976)

NASSAR, R.F. and Cook, R. D. Non-randomness of nucleotide bases in mRNA codons.

LaCy, George H. and Leary, JohN V. Plasmid-mediated transmission of chromosomal genes in Pseudomonas glycinea

DE BOER, P. Male meiotic behaviour and male and female litter size in mice with the $\mathrm{T}(2 ; 8) 26 \mathrm{H}$ and $\mathrm{T}(1 ; 13) 70 \mathrm{H}$ reciprocal translocations

HAYES, J.F. and MoCARTHY, J.C. The effects of selection at different ages for high and low body weight on the pattern of fat deposition in mice

Wong, C. L. and Duns, N. W. Combined chromosomal and plasmid encoded control for the degradation of phenol in Pseudomonas putida

Holliday, R., Halliwell, R. E., Evans, M. W. and Rowell, V. Genetic characterization of rec-1, a mutant of Ustilago maydis defective in repair and recombination

INDEX 
Genet. Res., Camb.

\section{GENETICAL \\ RESEARCH}

VOLUME 27, NUMBER 3, JUNE 1976

\section{CONTENTS}

NASSAR, R. F. and $\mathrm{coO}$, R. D. Non-randomness of nucleotide bases in mRNA codons

LACY, GEORGE H. and LEARY, JOHN v. Plasmid-mediated transmission of chromosomal genes in Pseudomonas glycinea

DE BOER, P. Male meiotic behaviour and male and female litter size in mice with the $\mathrm{T}(2 ; 8) 26 \mathrm{H}$ and $\mathrm{T}(1 ; 13) 70 \mathrm{H}$ reciprocal translocations

HAYES, J. F. and MCCARTHY, J. C. The effects of selection at different ages for high and low body weight on the pattern of fat deposition in mice

wONG, c. L. and DUNN, N. w. Combined chromosomal and plasmid encoded control for the degradation of phenol in Pseudomonas putida

holliday, R., halliwell, R. e., evans, M. W. and rowell, v. Genetic characterization of rec-1, a mutant of Ustilago maydis defective in repair and recombination 